\title{
Etiological Analyses of Marked Neonatal Hyperbilirubinemia in A Single Institution in Taiwan
}

\begin{abstract}
Shao-Wen Cheng, MD; Ya-Wen Chiu ${ }^{1,2}$, PhD; Yi-Hao Weng, MD
Background: Hyperbilirubinemia is a common disorder during the neonatal period. Severe neonatal hyperbilirubinemia $(\mathrm{NH})$ carries a potential for permanent neurological impairment. The current study analyzed possible etiologies leading to $\mathrm{NH}$.

Methods: $\quad$ A retrospective cohort of neonates with total serum bilirubin (TSB) $\geq 20$ $\mathrm{mg} / \mathrm{dL}$ was surveyed from 1995 to 2007 . Subjects with gestational ages $<34$ weeks were excluded, leaving a total of 413 enrolled neonates.

Results: The most common etiology in relation to marked NH was breast milk feeding $(38.5 \%)$, followed by glucose-6-phospahate dehydrogenase (G6PD) deficiency (24.0\%), ABO incompatibility (21.8\%), extravascular hemorrhage (6.5\%), Rh incompatibility (2.9\%), bacterial infection $(2.2 \%)$, hereditary spherocytosis $(1.2 \%)$, dehydration $(1.2 \%)$, diabetic mother $(1.0 \%)$, polycythemia $(0.7 \%)$, and gastrointestinal obstruction $(0.7 \%)$. Other rare etiologies included Down syndrome, Chinese herb intake, asphyxia, galactosemia and congenital hypothyroidism. We did not identify any known cause in 63 neonates $(15.3 \%)$. Neonates with more than one etiology tended to have higher TSB than subjects without a known etiology $(p<0.05)$. Anemia was more common in those with G6PD deficiency, blood group incompatibility, hereditary spherocytosis, and gastrointestinal obstruction. Neonates fed breast milk tended to have prolonged $\mathrm{NH}$.

Conclusion: This study depicts the clinical features of marked NH. Breast milk feeding, G6PD deficiency and ABO incompatibility are common etiologies in Taiwan. Prolonged NH is more common in neonates fed breast milk than those who were given formula.
\end{abstract}

(Chang Gung Med J 2012;35:148-54)

Key words: neonatal hyperbilirubinemia, total serum bilirubin, breast milk, G6PD deficiency, blood group incompatibility

$\mathrm{N}$ eonatal hyperbilirubinemia $(\mathrm{NH})$ is associated with a variety of conditions. Physiological aspects that contribute to $\mathrm{NH}$ include increased bilirubin production, less efficient hepatic conjuga-

tion, and enhanced bilirubin absorption by the enterohepatic circulation. ${ }^{(1)}$ In addition to physiologic jaundice, common identified pathologic causes include isoimmune hemolytic disease and glucose-6-

From the Division of Neonatology, Department of Pediatrics, Chang Gung Memorial Hospital at Taipei, Chang Gung University College of Medicine, Taoyuan, Taiwan; 'Division of Preventive Medicine and Health Services Research, Institute of Population Health Sciences, National Health Research Institutes, Miaoli, Taiwan; ${ }^{2}$ School of Public Health, Taipei Medical University, Taipei, Taiwan.

Received: Apr. 12, 2011; Accepted: Oct. 17, 2011

Correspondence to: Dr. Yi-Hao Weng, Division of Neonatology, Department of Pediatrics, Chang Gung Memorial Hospital at Taipei. 199, Dunhua N. Rd., Songshan District, Taipei City 105, Taiwan (R.O.C.) Tel: 886-2-27135211 ext. 3427;

Fax: 886-2-25457279; E-mail: yihaoweng@cgmh.org.tw 
phospahate dehydrogenase (G6PD) deficiency. ${ }^{(2-4)}$ Etiologies leading to NH carry a geographic difference. For instance, in one study from Singapore, NH was more common in babies of Chinese ethnic origin than those of Indian, Malay and other origins. ${ }^{(5)}$

Severe NH poses a direct threat of kernicterus, a permanent neurological sequel. ${ }^{(6,7)}$ Early identification of neonates at great risk of $\mathrm{NH}$ is of paramount importance in preventing brain damage. Total serum bilirubin (TSB) has been used as a surrogate index to evaluate the risk of adverse outcomes. Although a safe threshold for TSB has not been defined, most physicians have adopted a TSB $\geq 20 \mathrm{mg} / \mathrm{dL}$ as indicating vulnerability to neurotoxicity. ${ }^{(8)}$ In this study, the spectrums of neonates with $\mathrm{TSB} \geq 20 \mathrm{mg} / \mathrm{dL}$ are evaluated. We described the clinical features of marked NH according to etiological factors.

\section{METHODS}

Approval to collect data was granted by the Institutional Review Board of Chang Gung Memorial Hospital. Medical charts of newborns admitted to the neonatal intensive care units at Chang Gung Children's Hospital from 1995 to 2007 with TSB $\geq 20 \mathrm{mg} / \mathrm{dL}$ were reviewed. Neonates with either a direct bilirubin /TSB $>20 \%$ or gestational age $<34$ weeks were excluded. The direct bilirubin and TSB values were measured in a clinical laboratory with a Unistat bilirubinometer (Cambridge Instruments, Buffalo, NY, U.S.A.).

Patient data and clinical manifestations were obtained from medical charts. Mortality was defined as death occurring within 7 days after the development of marked hyperbilirubinemia without other known causes of death. Routine laboratory examinations included complete blood count, reticulocyte count blood smear, total and direct bilirubin, G6PD enzymatic activity, blood and urine cultures, blood type, and direct Coombs' test. In addition, data were collected from the national newborn screening for congenital hypothyroidism, galactosemia, G6PD deficiency, phenylketonuria, and homocystinuria. Any possible etiologies causing neonatal hyperbilirubinemia, including G6PD deficiency, diabetic mother, polycythemia, inborn error of metabolism (such as congenital hypothyroidism, galactosemia), hereditary spherocytosis, bacterial infection (such as sepsis, omphalitis, urinary tract infection), dehydration (defined as body weight loss of more than $10 \%$ of birth weight), gastrointestinal obstruction (defined as pathological obstruction requiring medical treatment, such as malrotation), exclusive breast feeding, extravascular hemorrhage (such as cephalohematoma, bruising, adrenal hemorrhage), Down syndrome, asphyxia, ABO incompatibility (any blood group A or B neonate of a group $\mathrm{O}$ mother), $\mathrm{Rh}$ incompatibility (Rh-positive infants born to Rhnegative mothers), were recorded. ${ }^{(1)}$ G6PD deficiency was confirmed with an enzyme activity below 12.5 U/gm Hb. Polycythemia was defined as a hematocrit value $>65 \%$ via venous sampling or $>63 \%$ via arterial sampling. Infants with spherocytosis on a blood smear were referred to pediatric hematologists for regular follow up. Hereditary spherocytosis was thereafter confirmed using an osmotic fragility assay.

The statistical analyses were conducted using SPSS for Windows, version 12.0 (SPSS Inc., IL, U.S.A.). Categorical variables were analyzed using the chi-square test or Fisher's exact test, and continuous variables were compared using the MannWhitney test. Significance was defined as $p<0.05$.

\section{RESULTS}

There were 413 neonates with TSB $\geq 20 \mathrm{mg} / \mathrm{dL}$ during the 13-year study period. Extreme hyperbilirubinemia, defined as TSB $\geq 25 \mathrm{mg} / \mathrm{dL}$, was noted in 111 neonates $(26.9 \%)$, with a TSB of 25 $29.9 \mathrm{mg} / \mathrm{dL}$ in $81(19.6 \%)$ neonates, $30-34.9 \mathrm{mg} / \mathrm{dL}$ $(4.1 \%)$ in $17,35-39.9 \mathrm{mg} / \mathrm{dL}(1.2 \%)$ in $5,40-44.9$ $\mathrm{mg} / \mathrm{dL} *(0.8 \%)$ in 3 , and $45-49.9 \mathrm{mg} / \mathrm{dL}(1.2 \%)$ in 5 . A total of 245 neonates were boys (59.3\%). In addition, 143 neonates were late preterm (34.6\%).

The etiologies in relation to $\mathrm{NH}$ are summarized in Table 1. The most common etiology was exclusive breast feeding (38.5\%), followed by G6PD deficiency $(24.0 \%)$, and $\mathrm{ABO}$ incompatibility $(21.8 \%)$. There were 63 neonates without an identified etiology $(15.3 \%)$. Neonates with $\mathrm{Rh}$ incompatibility included 6 mismatches in Rh D, 4 in Rh $\mathrm{E}$ and 2 in $\mathrm{Rh}$ E,c. Neonates with extravascular hemorrhage included 19 with cephalohematoma (4.6\%), 3 with massive bruising $(0.7 \%)$, 2 with subgaleal hemorrhage $(0.5 \%), 2$ with adrenal hemorrhage $(0.5 \%)$, and 1 with intracranial hemorrhage $(0.2 \%)$. Bacterial infection was found in 9 neonates, including 3 with sepsis (E. coli), 4 with omphalitis (E. coli) and 2 
Table 1. Etiology of Hyperbilirubinemia in Neonates

\begin{tabular}{|c|c|c|c|}
\hline Etiology & $\begin{array}{c}\mathrm{TSB} \geq 20 \\
\mathrm{mg} / \mathrm{dL} \\
\mathrm{N}=413 \\
\mathrm{n}(\%)\end{array}$ & $\begin{array}{c}\mathrm{TSB} \geq 25 \\
\mathrm{mg} / \mathrm{dL} \\
\mathrm{N}=111 \\
\mathrm{n}(\%)\end{array}$ & $\begin{array}{c}\mathrm{TSB} \geq 30 \\
\mathrm{mg} / \mathrm{dL} \\
\mathrm{N}=30 \\
\mathrm{n}(\%)\end{array}$ \\
\hline Exclusive breast feeding & $159(38.5)$ & $38(34.2)$ & $9(30.0)$ \\
\hline G6PD deficiency & $99(24.0)$ & $41(36.9)$ & $18(60.0)$ \\
\hline ABO incompatibility & $90(21.8)$ & $26(23.4)$ & $5(16.7)$ \\
\hline Unknown & $63(15.3)$ & $12(10.8)$ & $2(6.7)$ \\
\hline Extravascular hemorrhage & $27(6.5)$ & $4(3.6)$ & $1(3.3)$ \\
\hline Rh incompatibility & $12(2.9)$ & $7(6.3)$ & $2(6.7)$ \\
\hline Bacterial infection & $9(2.2)$ & $4(3.6)$ & $2(6.7)$ \\
\hline Hereditary spherocytosis & $5(1.2)$ & $2(1.8)$ & $0(0)$ \\
\hline Dehydration & $5(1.2)$ & $2(1.8)$ & $0(0)$ \\
\hline Diabetic mother & $4(1.0)$ & $1(0.9)$ & $0(0)$ \\
\hline Polycythemia & $3(0.7)$ & $1(0.9)$ & $0(0)$ \\
\hline Paralytic ileus & $2(0.5)$ & $1(0.9)$ & $0(0)$ \\
\hline Malrotation & $1(0.2)$ & $1(0.9)$ & $1(3.3)$ \\
\hline Down syndrome & $1(0.2)$ & $1(0.9)$ & $0(0)$ \\
\hline Chinese herb intake & $1(0.2)$ & $1(0.9)$ & $1(3.3)$ \\
\hline Asphyxia & $1(0.2)$ & $1(0.9)$ & $0(0)$ \\
\hline Galactosemia & $1(0.2)$ & $0(0)$ & $1(0.2)$ \\
\hline Congenital hypothyroidism & $1(0.2)$ & $1(0.9)$ & $1(0.2)$ \\
\hline
\end{tabular}

Abbreviations: TSB: total serum bilirubin; G6PD: glucose-6-phospahate dehydrogenase.

with urinary tract infection (Klebsiella pneumoniae, Enterobacter cloacae). In addition, 3 neonates had gastrointestinal tract obstruction. One infant had organic obstruction caused by malrotation. This patient had a peak TSB level just after surgical treatment. Two neonates had paralytic ileus with the clinical manifestations of abdominal distension and vomiting.

The most common etiology in neonates with extreme hyperbilirubinemia (defined as TSB $\geq 25$ $\mathrm{mg} / \mathrm{dL}$ ) was G6PD deficiency (36.9\%), followed by exclusive breast feeding (34.2\%), and ABO incompatibility (23.4\%). Similarly, the most common etiology in infants with TSB $\geq 30 \mathrm{mg} / \mathrm{dL}$ was G6PD deficiency $(60.0 \%)$, followed by exclusive breast feeding (30.0\%), and $\mathrm{ABO}$ incompatibility (16.7\%).

The correlation of TSB with the number of etiological factors is shown in Table 2. The TSB in neonates with two or more etiologies was significantly higher than those with an unknown etiology.
Table 2. Correlation of Total Serum Bilirubin with the Number of Etiological Factors

\begin{tabular}{cccc}
\hline Number & $\mathrm{n}(\%)$ & $\begin{array}{c}\text { Total serum } \\
\text { bilirubin }(\mathrm{mg} / \mathrm{dL})\end{array}$ & $p$ value \\
\hline 0 & $63(15.3)$ & $22.7 \pm 3.1$ & reference group \\
1 & $288(69.7)$ & $23.6 \pm 4.2$ & 0.090 \\
2 & $54(13.1)$ & $24.6 \pm 4.7$ & 0.012 \\
$>2$ & $8(1.9)$ & $30.8 \pm 10.4$ & 0.009 \\
\hline
\end{tabular}

We further evaluated the clinical characteristics by etiology. Neonates with more than one etiology were eliminated in an attempt to better understand the profile of each etiology (Table 3). In infants with a hemoglobin level $<14 \mathrm{~g} / \mathrm{dL}$, those with $\mathrm{Rh}$ incompatibility had the lowest average hemoglobin, followed by those with hereditary spherocytosis, G6PD deficiency, $\mathrm{ABO}$ incompatibility and gastrointestinal tract obstruction. In addition, prolonged $\mathrm{NH}$ (defined as age at peak TSB $>15$ days old) was found only in neonates fed breast milk. Neonates with an average age at peak TSB of less than 3 days old included those with $\mathrm{ABO}$ incompatibility, hereditary spherocytosis and $\mathrm{Rh}$ incompatibility.

\section{DISCUSSION}

Although NH has been thoroughly evaluated, there are few reports on the manifestations within different etiologies. ${ }^{(9)}$ There are often multiple reasons causing $\mathrm{NH}$ in a given neonate. Combined etiologies may result in greater severity of $\mathrm{NH} .{ }^{(10)} \mathrm{We}$ omitted neonates with multiple etiologies to better understand the manifestations of NH caused by a single factor. To our knowledge, the current study is the first to compare the clinical presentations of $\mathrm{NH}$ by etiological factor.

Overall, exclusive breast feeding was the most common cause of NH. There are an increasing number of studies showing that breast feeding is the most important factor leading to $\mathrm{NH} .{ }^{(11-14)}$ We found that $\mathrm{NH}$ caused by breast feeding increased significantly after the governmental initiative to encourage breast feeding which began in 2001 (1995-2001: 2002-2007 = 25\%: 50\%). A similar report from Huang et al. also showed an increase of $\mathrm{NH}$ after global promotion of this policy. ${ }^{(15)}$ In particular, our study demonstrated all neonates with prolonged $\mathrm{NH}$, defined as 
Table 3. Laboratory and Patient Information for 288 Neonates with a Single Etiological Factor.

\begin{tabular}{|c|c|c|c|}
\hline Etiology & $\begin{array}{c}\mathrm{TSB}(\mathrm{mg} / \mathrm{dL}) \\
\text { mean } \pm \mathrm{SD}(\text { range })\end{array}$ & $\begin{array}{l}\text { Hemoglobin }(\mathrm{g} / \mathrm{dL}) \\
\text { mean } \pm \mathrm{SD}(\text { range })\end{array}$ & $\begin{array}{l}\text { Age at peak TSB (d) } \\
\text { mean } \pm \text { SD (range) }\end{array}$ \\
\hline Exclusive breast feeding $(\mathrm{n}=118)$ & $22.8 \pm 2.8(20.0-32.5)$ & $14.9 \pm 2.1(9.3-19.4)$ & $9.73 \pm 5.60(3-30)$ \\
\hline G6PD deficiency $(\mathrm{n}=61)$ & $25.6 \pm 6.6(20.1-47.2)$ & $13.1 \pm 2.7(7.5-19.6)$ & $6.92 \pm 3.16(3-15)$ \\
\hline ABO incompatibility $(\mathrm{n}=63)$ & $23.3 \pm 3.2(20.0-38.6)$ & $13.4 \pm 2.3(8.7-18.0)$ & $3.70 \pm 2.08(1-8)$ \\
\hline Extravascular hemorrhage $(n=14)$ & $21.1 \pm 1.2(20.0-24.0)$ & $14.1 \pm 2.3(10.1-17.0)$ & $4.57 \pm 1.60(3-8)$ \\
\hline Rh incompatibility $(\mathrm{n}=10)$ & $26.1 \pm 3.0(22.0-30.7)$ & $11.3 \pm 2.2(8.7-15.4)$ & $2.60 \pm 1.43(1-5)$ \\
\hline Bacterial infection $(\mathrm{n}=4)$ & $23.6 \pm 2.8(20.7-27.2)$ & $16.6 \pm 1.5(14.7-18.0)$ & $3.50 \pm 0.58(3-4)$ \\
\hline Hereditary spherocytosis $(n=3)$ & $23.8 \pm 3.3(21.6-27.6)$ & $12.4 \pm 0.3(12.1-12.7)$ & $1.67 \pm 0.58(1-2)$ \\
\hline Dehydration $(\mathrm{n}=5)$ & $23.3 \pm 3.1(20.5-27.9)$ & $16.2 \pm 2.2(13.7-19.2)$ & $8.40 \pm 4.45(6-15)$ \\
\hline Diabetic mother $(\mathrm{n}=3)$ & $21.1 \pm 1.1(20.1-22.2)$ & $15.6 \pm 0.2(15.4-15.8)$ & $3.67 \pm 0.58(3-4)$ \\
\hline Polycythemia $(\mathrm{n}=2)$ & $23.1 \pm 0.1(23.0-23.2)$ & $20.1 \pm 2.1(18.6-21.5)$ & $5.00 \pm 2.83(3-7)$ \\
\hline Gastrointestinal tract obstruction $(\mathrm{n}=2)$ & $29.6 \pm 11.5(21.5-37.7)$ & $13.4 \pm 0.8(12.8-13.9)$ & $5.50 \pm 0.71(5-6)$ \\
\hline Down syndrome $(\mathrm{n}=1)$ & 26.0 & 15.8 & 9 \\
\hline Galactosemia $(\mathrm{n}=1)$ & 20.9 & 17.6 & 3 \\
\hline Chinese herb intake $(\mathrm{n}=1)$ & 33.8 & 17.2 & 5 \\
\hline
\end{tabular}

Abbreviations: TSB: total serum bilirubin; G6PD: glucose-6-phospahate dehydrogenase.

$\mathrm{NH}$ noted at age $>15$ days, were fed breast milk. Although breast feeding has been encouraged because it has many advantages, its impact on $\mathrm{NH}$ still raises concerns. However, the risk of long-term neurological complications (kernicterus) with this etiology is very low. ${ }^{(2)} \mathrm{NH}$ resolves spontaneously within a few months in breast-fed infants. Therefore, $\mathrm{NH}$ caused by breast feeding has been treated with a gentle approach. Our previous report also showed that breast milk feeding carries no significant risk for kernicterus. ${ }^{(16)}$ Bilirubin has been proposed as an effective antioxidant, and modest elevations of bilirubin may be beneficial in compromised neonates. ${ }^{(17)}$ Further studies are needed to investigate the pathophysiological mechanism of breast milk feeding leading to $\mathrm{NH}$.

ABO incompatibility and G6PD deficiency were also common causes of $\mathrm{NH}$ in this study, and other studies. ${ }^{(2-4,9,18)}$ Anemia is more common in these two groups, indicating that hemolysis plays an important role in the development of $\mathrm{NH} .{ }^{(3,4,19)}$

Previous investigations have documented an association between $\mathrm{NH}$ and bacterial infection, especially sepsis and urinary tract infection. ${ }^{(20-24)}$ How bacterial infection causes NH is not clear. An induction of heme oxygenase-1, the rate-limiting enzyme in bilirubin production, has been proposed as the mechanism. ${ }^{(17,25)}$ In our study, 3 neonates with sepsis were all infected by E. coli, which is the most common gram-negative pathogen during the newborn period. ${ }^{(20,21)}$ Furthermore, our study demonstrated that urinary tract infection was an infrequent cause of NH. The pathogens in the urinary tract infections were gram-negative bacilli. There has been a debate on routine urine cultures for well infants with $\mathrm{NH} .{ }^{(26)}$ In this study, neonates with urinary tract infection developed clinical manifestations other than $\mathrm{NH}$. Our study also found $E$. coli was the most common pathogen in infants with omphalitis. Taken together, the data suggest that neonates infected by gram-negative bacilli are more susceptible to $\mathrm{NH}$.

In our study, the incidence of hereditary spherocytosis was $1.2 \%$, which was much higher than in the overall population. Similar findings were observed by Saada et al. ${ }^{(27)}$ There is difficulty in the diagnosis of hereditary spherocytosis at birth, leading to an underestimation of its correlation with $\mathrm{NH}{ }^{(28,29)}$ Infants with hereditary spherocytosis often develop early $\mathrm{NH}$, similar to those with blood group incompatibility. Although hemolysis is the contributor to $\mathrm{NH}$, only a few cases developed extreme $\mathrm{NH}$ requiring exchange transfusion. ${ }^{(30,31)}$

Infants of diabetic mothers have an increased risk of $\mathrm{NH}$. Neonates born to diabetic mothers who 
have macrosomia tend to have bruising at birth, and resorption of subcutaneous blood can contribute to $\mathrm{NH}{ }^{(32)}$ In addition, some rare etiologies leading to $\mathrm{NH}$ were identified in this study. We found two neonates with inborn error of metabolism disorders. Galactosemia has been documented as an uncommon presentation of early-onset $\mathrm{NH}{ }^{(33)}$ Furthermore, neonates with Down syndrome or congenital hypothyroidism may develop $\mathrm{NH}$ beyond the age of physiological jaundice. ${ }^{(34,35)}$ Our study also found gastrointestinal tract obstruction was a contributor to NH. It's well known that a lower gastrointestinal tract obstruction increases the absorption of bilirubin. ${ }^{(1)}$ In our study, one neonate received a proprietary preparation of Chinese herbs. There has been little monitoring of Chinese medicine in neonates. ${ }^{(36)}$ Therefore, parents should be discouraged from treating their neonates with herbal medicine.

There were some limitations to this study. First, the pattern of etiological factors may have great geographic variations. Therefore, our findings may not apply in other countries. Second, the cause of $\mathrm{NH}$ could not be determined in a substantial number of neonates in this study. Some potential factors leading to $\mathrm{NH}$ were not examined, such as Gilbert syndrome. ${ }^{(37)}$ In most of these neonates, peak TSB levels were reached on the third to sixth day after birth with normal limits of hematologic parameters. Thus, they may display a severe form of physiologic jaundice. Third, some etiologies were present in only few subjects and, as a result, interpretation of data from these patients should be done cautiously.

In conclusion, our study disclosed the clinical features of marked $\mathrm{NH}$ within different etiologies. Breast milk feeding, G6PD deficiency and $\mathrm{ABO}$ incompatibility are common etiologies of $\mathrm{NH}$ in Taiwan. Prolonged NH is more common in neonates fed breast milk. In particular, we reported the manifestations of $\mathrm{NH}$ caused by uncommon etiologies. Clinicians may distinguish the etiological factor according to the clinical presentation of $\mathrm{NH}$.

\section{REFERENCES}

1. Dennery PA, Seidman DS, Stevenson DK. Neonatal hyperbilirubinemia. N Engl J Med 2001;344:581-90.

2. Maisels MJ, Bhutani VK, Bogen D, Newman TB, Stark AR, Watchko JF. Hyperbilirubinemia in the newborn infant $>$ or $=35$ weeks' gestation: an update with clarifi- cations. Pediatrics 2009;124:1193-8.

3. Weng YH, Chiu YW. Clinical characteristics of G6PD deficiency in infants with marked hyperbilirubinemia. J Pediatr Hematol Oncol 2010;32:11-4.

4. Weng YH, Chiu YW. Spectrum and outcome analysis of marked neonatal hyperbilirubinemia with blood group incompatibility. Chang Gung Med J 2009;32:400-8.

5. Huang A, Tai BC, Wong LY, Lee J, Yong EL. Differential risk for early breastfeeding jaundice in a multi-ethnic Asian cohort. Ann Acad Med Singapore 2009;38:217-24.

6. Bhutani VK, Johnson L. Kernicterus in late preterm infants cared for as term healthy infants. Semin Perinatol 2006;30:89-97.

7. Shapiro SM. Bilirubin toxicity in the developing nervous system. Pediatr Neurol 2003;29:410-21.

8. Watchko JF. Vigintiphobia revisited. Pediatrics 2005;115: 1747-53.

9. Ebbesen F, Andersson C, Verder H, Grytter C, PedersenBjergaard L, Petersen JR, Schaarup J. Extreme hyperbilirubinaemia in term and near-term infants in Denmark. Acta Paediatr 2005;94:59-64.

10. Huang MJ, Kua KE, Teng HC, Tang KS, Weng HW, Huang CS. Risk factors for severe hyperbilirubinemia in neonates. Pediatr Res 2004;56:682-9.

11. Salas AA, Mazzi E. Exchange transfusion in infants with extreme hyperbilirubinemia: an experience from a developing country. Acta Paediatr 2008;97:754-8.

12. Sgro M, Campbell D, Shah V. Incidence and causes of severe neonatal hyperbilirubinemia in Canada. CMAJ 2006;175:587-90.

13. Bertini G, Dani C, Tronchin M, Rubaltelli FF. Is breastfeeding really favoring early neonatal jaundice? Pediatrics 2001;107:E41.

14. Gartner LM, Herschel M. Jaundice and breastfeeding. Pediatr Clin North Am 2001;48:389-99.

15. Huang MS, Lin MC, Chen HH, Chien KL, Chen CH. Risk factor analysis for late-onset neonatal hyperbilirubinemia in Taiwanese infants. Pediatr Neonatol 2009;50: 261-5.

16. Weng YH, Chiu YW, Cheng SW, Hsieh MY. Risk assessment for adverse outcome in term and late preterm neonates with bilirubin value of $20 \mathrm{mg} / \mathrm{dL}$ or more. Am J Perinatol 2011;28:405-12.

17. Dennery PA, Weng YH, Stevenson DK, Yang G. The biology of bilirubin production. J Perinatol 2001;21:S1720.

18. Weng YH, Chou YH, Lien RI. Hyperbilirubinemia in healthy neonates with glucose-6-phosphate dehydrogenase deficiency. Early Hum Dev 2003;71:129-36.

19. Weng YH, Chou YH. Glucose-6-phosphate dehydrogenase deficiency with hyperbilirubinemia in neonates born inside and outside a tertiary hospital. Clin Neonatal 2003;10:50-3.

20. Chavalitdhamrong PO, Escobedo MB, Barton LL, Zarkowsky H, Marshall RE. Hyperbilirubinaemia and 
bacterial infection in the newborn. A prospective study. Arch Dis Child 1975;50:652-4.

21. Linder N, Yatsiv I, Tsur M, Matoth I, Mandelberg A, Hoffman B, Yevin R, Tamir I. Unexplained neonatal jaundice as an early diagnostic sign of septicemia in the newborn. J Perinatol 1988;8:325-7.

22. Ng SH, Rawstron JR. Urinary tract infections presenting with jaundice. Arch Dis Child 1971;46:173-6.

23. Lee HC, Fang SB, Yeung CY, Tsai JD. Urinary tract infections in infants: comparison between those with conjugated vs unconjugated hyperbilirubinaemia. Ann Trop Paediatr 2005;25:277-82.

24. Bilgen H, Ozek E, Unver T, Biyikli N, Alpay H, Cebeci D. Urinary tract infection and hyperbilirubinemia. Turk J Pediatr 2006;48:51-5.

25. Weng YH, Yang G, Weiss S, Dennery PA. Interaction between heme oxygenase-1 and -2 proteins. J Biol Chem 2003;278:50999-1005.

26. Satwik V, Booth D. An audit of urine culture results in well infants attending a prolonged jaundice clinic. Arch Dis Child 2009;94:914.

27. Saada V, Cynober T, Brossard Y, Schischmanoff PO, Sender A, Cohen H, Delaunay J, Tchernia G. Incidence of hereditary spherocytosis in a population of jaundiced neonates. Pediatr Hematol Oncol 2006;23:387-97.

28. Delhommeau F, Cynober T, Schischmanoff PO, Rohrlich P, Delaunay J, Mohandas N, Tchernia G. Natural history of hereditary spherocytosis during the first year of life. Blood 2000;95:393-7.

29. Christensen RD, Henry E. Hereditary spherocytosis in neonates with hyperbilirubinemia. Pediatrics 2010;125:
$120-5$.

30. Mariani M, Barcellini W, Vercellati C, Marcello AP, Fermo E, Pedotti P, Boschetti C, Zanella A. Clinical and hematologic features of 300 patients affected by hereditary spherocytosis grouped according to the type of the membrane protein defect. Haematologica 2008;93:13107.

31. Weng YH, Chiu YW. Comparison of efficacy and safety of exchange transfusion through different catheterizations: femoral vein versus umbilical vein versus umbilical artery/vein. Pediatr Crit Care Med 2011;12:61-4.

32. Barnes-Powell LL. Infants of diabetic mothers: the effects of hyperglycemia on the fetus and neonate. Neonatal Netw 2007;26:283-90.

33. Woo HC, Phornphutkul C, Laptook AR. Early and severe indirect hyperbilirubinemia as a manifestation of galactosemia. J Perinatol 2010;30:295-7.

34. Kaplan M, Vreman HJ, Hammerman C, Stevenson DK. Neonatal bilirubin production, reflected by carboxyhaemoglobin concentrations, in Down's syndrome. Arch Dis Child Fetal Neonatal Ed 1999;81:F56-60.

35. Weldon AP, Danks DM. Congenital hypothyroidism and neonatal jaundice. Arch Dis Child 1972;47:469-71.

36. Chan TY, Critchley JA. Usage and adverse effects of Chinese herbal medicines. Hum Exp Toxicol 1996;15:512.

37. Kaplan M. Genetic interactions in the pathogenesis of neonatal hyperbilirubinemia: Gilbert's Syndrome and glucose-6-phosphate dehydrogenase deficiency. J Perinatol 2001;21:S30-4. 


\title{
嚴重新生兒高膽紅素血症之病因性分析〜 某單一醫療機構之研究
}

\author{
程劭文 邱亞文 ${ }^{1,2}$ 翁逸豪
}

背 景: 高膽紅素是新生兒時期常見的疾病。膽紅素過高可能造成永久性的神經傷害, 本回 溯性研究即探討新生兒嚴重黄㾝之病因性分析。

方 法: 研究對象爲 1995 年至 2007 年膽紅素超過 $20 \mathrm{mg} / \mathrm{dL}$ 之新生兒, 排除出生週數<34 週 之早產兒, 共收案 413 位新生兒。

結 果: 造成新生兒高膽紅素血症最常見之原因爲純母乳哺餵 $(38.5 \%)$, 其次爲蛀豆症 $(24.0 \%) 、 A B O$ 血型不相容 $(21.8 \%) 、$ 血管外出血 $(6.5 \%) 、 R h$ 血型不相容 $(2.9 \%)$ 、細 菌感染 $(2.2 \%)$ 、遺傳性非球性紅細胞貧血 $(1.2 \%)$ 、脱水 $(1.2 \%)$ 、母親糖尿病之嬰兒 $(1.0 \%)$ 、紅血球增多症 $(0.7 \%)$ 、腸道阻塞 $(0.7 \%)$ 。其他少見之病因包括唐氏症、服用 中藥、窒息、半乳糖血症及先天甲狀腺機能不足。本研究共有 63 位新生兒找不到明 確的病因 $(15.3 \%)$ 。具有一項以上病因的新生兒其血清總膽紅素較没有病因的新生兒 爲高 $(p<0.05)$ 。䖝豆症、血型不相容 $(21.8 \%)$ 、遺傳性非球性紅細胞貧血、腸道阻塞 較會有貧血之現象。延䐅性新生兒高膽紅素血症較會出現在純母乳哺揋之嬰兒。

結 論：本研究提供了嚴重新生兒高膽紅素血症的臨床表現，尤其是少見病因的探討。本研 究進一步探討各個病因在臨床上的差異性, 發現純母乳哺揋之嬰兒較容易出現延痋 性之新生兒高膽紅素血症。

(長庚醫誌 2012;35:148-54)

關鍵詞：高膽紅素血症，血清總膽紅素，母乳，䖝豆症，血型不相容

長庚醫療財團法人台北長庚紀念醫院 兒童內科部 新生兒科; 長庚大學 醫學院; 1國家衛生研究院 群體健康研究所; 2 台 北醫學大學 公共衛生學院

受文日期：民國100年4月12日；接受刊載：民國100年10月17日

通訊作者: 翁逸豪醫師, 長庚醫療財團法人台北長庚紀念醫院 兒童內科部 新生兒科。台北市105敦化北路199號。

Tel: (02)27135211轉3427; Fax: (02)25457279; E-mail: yihaoweng@cgmh.org.tw 